\title{
近隣型商店街における「住一商」関係別にみた商人家族の居住特性
}

\section{HABITATION CHARACTERISTIC OF MERCHANT FAMILY IN NEIGHBORING SHOPPING DISTRICT ANALYSED FROM RELATION BETWEEN COMMERCIAL ACTIVITY AND LIVING}

\author{
藤 岡 泰 寛*1, 大原一興*2, 小滝一正*3 \\ Yasuhiro FUJIOKA, Kazuoki OHARA and Kazumasa OTAKI
}

\begin{abstract}
The purpose of this paper is to make clear habitation characteristic of merchant family who work in the neighboring shopping district. In this paper, we cleared that the habitation characteristic is influenced by the local characteristic where shop exists, the age which shop is opened and the right of shop-ownership. But the desire to live in the neighborhood is not influenced by such things. So we have concluded that it can be said that it is neccessary to consider about various types and systems of self-owned shop, and also consider about attractive place of residence in the neighborhood.
\end{abstract}

Keywords: $\quad$ Habitation characteristic, Neighboring shopping district, Merchant family 居住特性、近隣型商店街、商人家族

\section{1 研究の背景と目的}

近年、最寄り品を中心とした近隣型商店街の衰退・停滞による 「まちコミュニティ」の希薄化が問題視されている。既成市街地に おけるこうした問題は、商業振興上の問題として、あるいは、都 市計画上の問題として議論されることが多い注1) が、一方で、「空 き店舗の増加」「後継者不足」など、現在指摘されている問題の多 くは、個々の商店、特に個々の商人注2) 家族の経年的な変化にとも なって表出した結果であるとも言える。

その背景には、「商（あきな）い」と「暮らし」の関係を、日々 の生活の中でどのように折り合いをつけていくか、という事情が 大きく影響していると考えられる。「商い」の場と「暮らし」の場 の関係の断絶は、地域との関わりを持たない商人、つまり、商人 家族の地域外居住の動向を分析することにより端的に理解できる と考えられる。

商人家族の地域外居住の問題は、一般的に認識されてはいる非3 が、その実態は明らかにされていない注4)。そこで本研究では、居 住・生活の場と商業の場との一体か分離か、という地理的関係や 各々の所有のされ方を「住一商」関係とし、この視点からの分析 により、近隣型商店街における商人家族の「住一商」関係のあり 方について居住計画的な側面から考察することを目的としている。

\section{2 研究の対象と方法}

全国の商店街の数は任意団体も含めると 15,000 ～18,000 団体 あると言われている注5)。その多くが戦後から高度成長期にかけて 確立した近隣型商店街㣖6)であり、成立時期に大きな地域偏差はな いものと考えられる。

しかしながら、商店の立地・集積は周辺環境の影響を強く受け ることから、本研究では、都心部の比較的古くから市街化が進ん でいる地域（横浜市保土ヶ谷区）と、郊外部の比較的最近宅地開 発が進んでいる地域（横浜市金沢区）の両者を調查対象地域とし て選定（図 1）し、両区における近隣型商店街の商人へのアン ケート調查、および、補足的に聞き取り調查を実施した。

アンケート調査の際には、（社）横浜市商店街総連合会発行の 「横浜市商店街要覧」(平成 12 年) を参照し、開業時期、“業種、商 店の使途の変化、住み替えの傾向と動機などについて耐ねた。配 布数、回収数および回収率は表 1 の通りである。

また、補足的に実施した聞き取り調査については、横浜市金沢 区金沢八景駅前商店街で営業を行っている商人 10 名に対し店舗史 と住居史、および両者の関係について尋ねた。

いずれの調査についても、回答者は商店の代表者に限定して実 施した。
*1 横浜国立大学大学院工学研究院 助手·工修

*2 横浜国立大学大学院工学研究院 助教授・工博

*3 横浜国立大学大学院工学研究院 教授・工博
Research Assoc., Dept. of Architecture, Faculty of Engineering, Yokohama National Univ.; M. Eng.

Assoc. Prof., Dept. of Architecture, Faculty of Engineering; Yokohama National Univ., Dr. Eng.

Prof., Dept. of Architecture, Faculty of Engineering, Yokohama National Univ., Dr. Eng. 


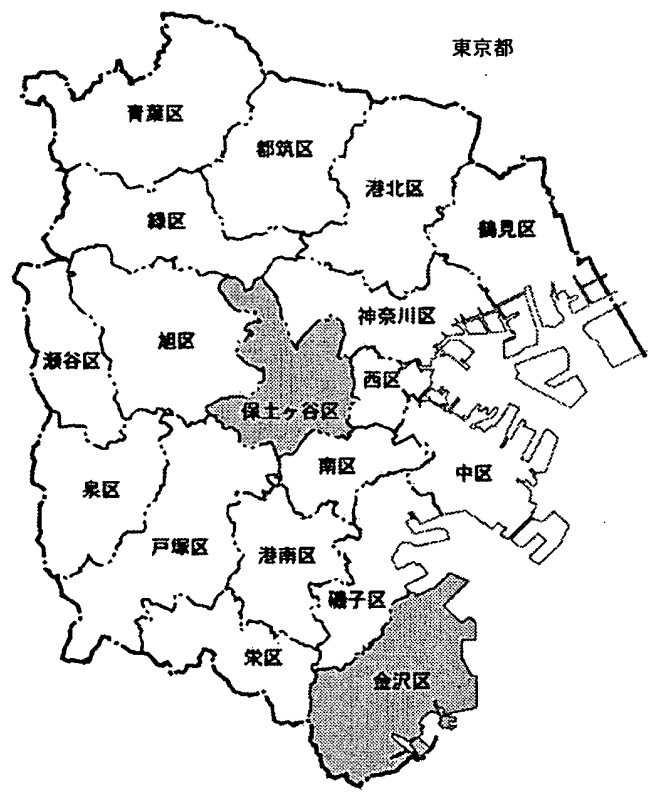

图1調查対象地域（神宗川県横浜市）

表 1 アンケート略查嗳要

\begin{tabular}{|c|c|c|c|c|c|c|}
\hline & 对筧商店苗 & 距布数 & 回收数(有奻) & 回收事 & 䀦查時期 & 畞奋方法 \\
\hline 保土ケ谷区缃直 & 12 & 632 & 225 & $35.60 \%$ & 2003.2 & 郋送法（配布 - 回収其） \\
\hline 金沢区明查 & 18 & 796 & 212 & $26.60 \%$ & 2001.12 & 期送法（即布 · 回収共） \\
\hline
\end{tabular}

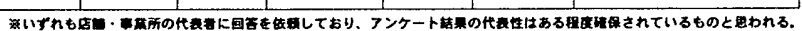

\section{3 アンケート調査結果と考察}

商人家族の居住特性について分析・考察する際に、いくつか重 要な視点が考えられるが、本研究では、基本的属性をふまえた上 で、「商店の使途」および、商人家族の「現居住地」「住み替え動 向」「居住地選択の要因」の大きく4つの視点から分析を進めるこ ととする。なお、それぞれの視点において、商店の所有形態別、 および、商店の立地する地域別に考察を加えることとする。

\section{1 基本的属性}

まず、商店の開業時期については、戦後復興期と高度成長期に 集中しており、現在の近隣型商店街が昭和期に確立したものであ ることが分かる（表 2)。また、商人の年歯は 50 代・60 代が中心 であり、商人の $60 \%$ 以上が初代の創業者であることから、創業後 代替わりすることなく高齢化しつつあることが分かる（表 3、表 4)。地域別にみると、金沢区に比べて、保土ヶ谷区はその傾向が やや強い。業種は小売業と飲食業で全体の約 $2 / 3$ を占めている (表 5)。

商店の所有形態別にみると、自地自店・借地借店のほかに借地 自店の場合が相当数含まれている。これは、戦後まもなくのころ に土地が細分化され、個別に自店を持ったまま現在に至っている 為であると考えられる (表6、表 7)。
表2 商店の閊業时期

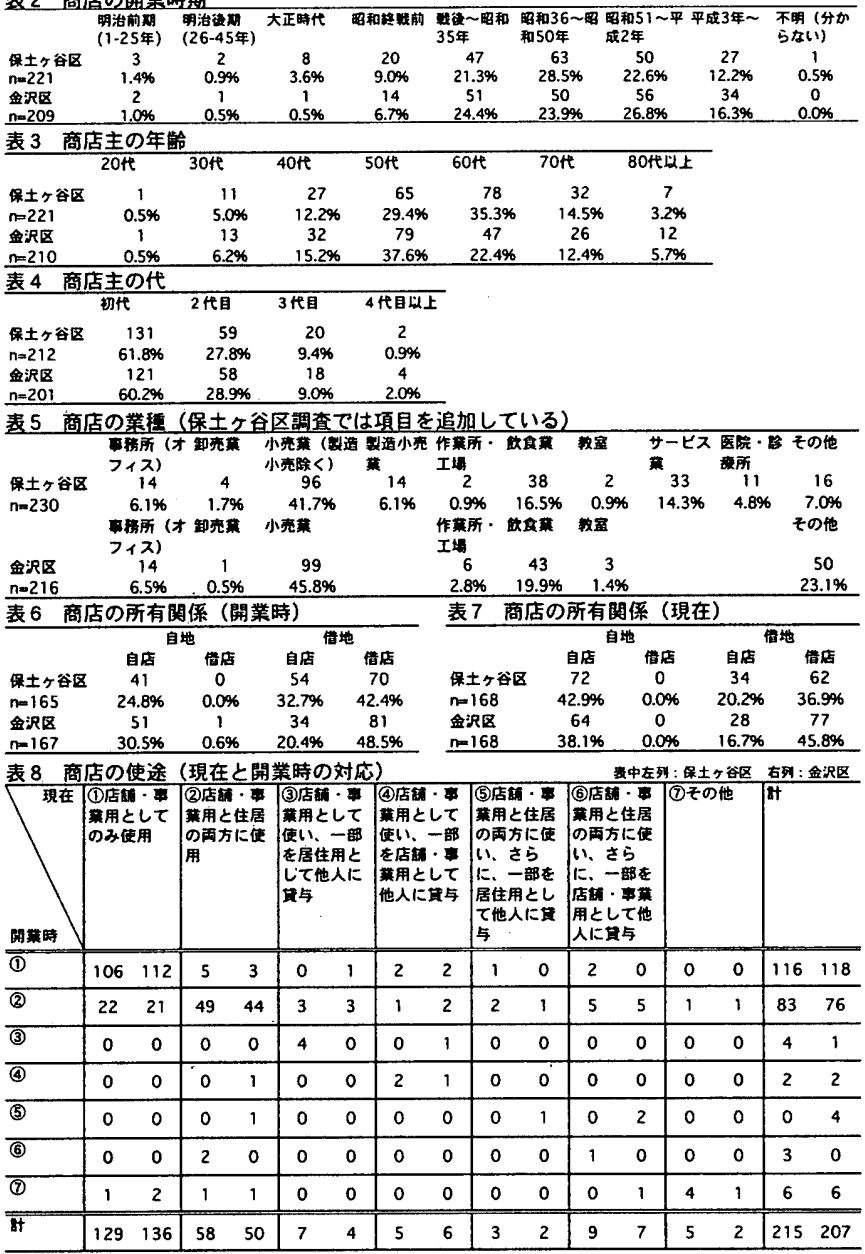

表 9 現在の商店の使途（所有形紧との対㐫・保土ヶ谷区）

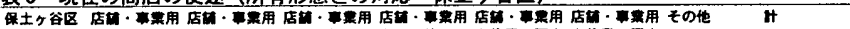

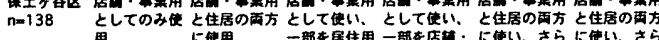

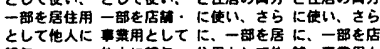

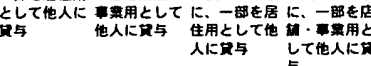

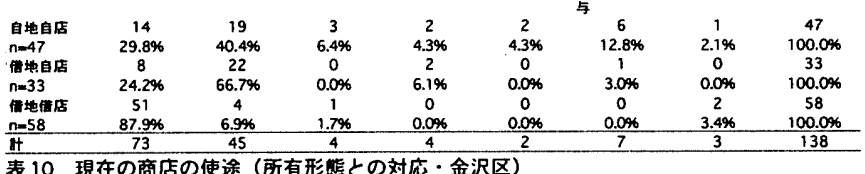

表 10 現在の商店の使途（所有形悠との対応・金沢区

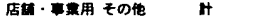

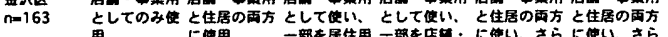

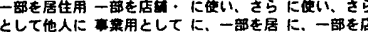

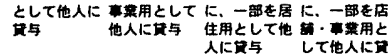

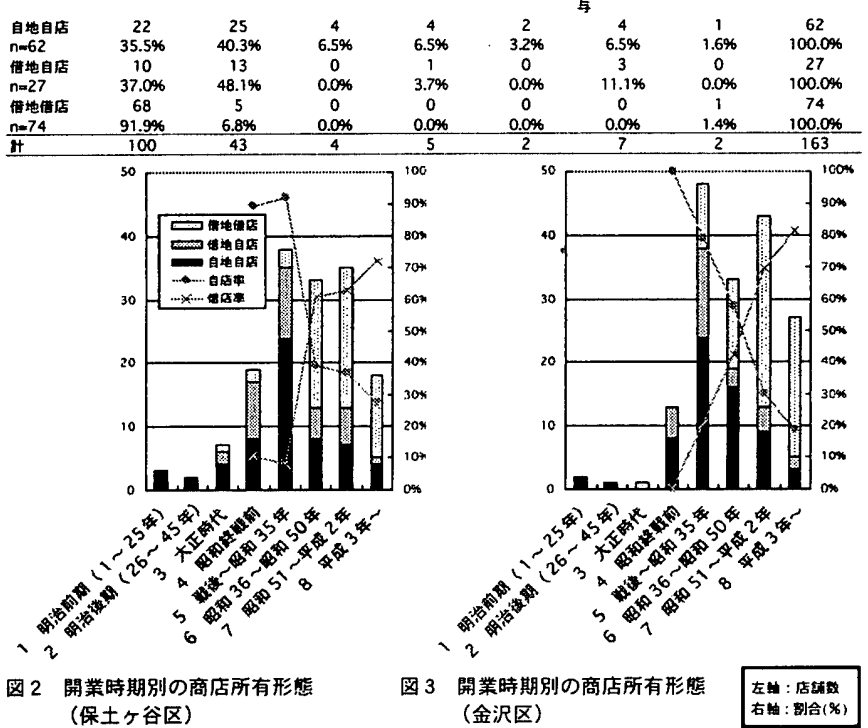




\section{2 商店の使途}

次に、現在の商店の使途を開業時のそれと比較したところ、表 8 のように、「店舗・事業所としてのみ使用」し続けている商人が 全体の約半数、「店舗・事業所と住まいの両方に使用」し続けてい る商人が全体の約 $1 / 4$ となったが、開業時「店舗・事業所と住 まいの両方に使用」していたが、途中で「店舗・事業所としての み使用」へと変化した商人が全体の約 1 割いることが分かった。

現在の商店の使途を所有形態に見ると、店舗専用としての使用 は借地借店人（以降「借店人」注7)）に多く見られ、住居併用とし ての使用は借地自店人や自地自店人（以降「自店人」）に多く見ら れることが分かる（表 9、表 $10^{\text {注 } 8)}$ )。

開業時期別に現在の所有形態をみると、高度成長期に借店率と 自店率注9）の逆転現象がみられ、これ以降、借店率は增加傾向、自 店率は減少傾向を示していることが分かる注10)。既往研究注11) よ り、商店の所有形態は開業後に大きく変化せず固定化する傾向に あることが分かっており、この推移は一時的なものではないと考 えられる（図2、図3）。

また、一口に商店といってもその業種はさまざまであり、業種 の違いは少なからず開業後の「住一商」関係に影響を与えている ものと考えられる。

表 11、表 12 注 12) は業種毎の現在の商店の使途をまとめたもの である。ここでは、「店舗・事業所のみの使用」「店舗・事業所と 住居の両方に使用」の 2 つの使用形態について示してある。

表 5 に示されたように、小売店と飲食店は近隣型商店街の典型 と言える業種であるが、表 11 、表 12 によると、小売店は比較的 住居併用の割合が高いのに対し、飲食店は逆に店舗専用としての 使用の割合が高いことが特徵的である。

ここまでの分析について、地域別に概観すると、保土ヶ谷区に おいて、小売商店の住居併用の割合が比較的高いほかは目立った 差は見られない。

\section{3 現居住地の特徵}

商人家族の現居住地について、商店からの距離と所有形態およ び商店主の年齢の関係について整理したものが表 $13 \sim 18^{\text {i土 }}$ 13) で ある。表 13、表 14 によると、全体としては、住居併用が約 1 ／ 3 、住居非併用が約 $2 / 3$ である。

非併用の中で見ると、徒歩 7 ～8 分程度（約 $500 \mathrm{~m}$ 圈内）まで で約 $2 / 5$ 、徒歩 15 分程度（約 $1 \mathrm{~km}$ 圈内）まで含めると過半数 を占めている一方で、車や電車等を利用しないと通えない商人家 族も約 $1 / 3$ 存在していることがわかる。

商店主の年齢別に見ると、住居併用の居住形態は高齢の商店主 に、車や電車等を利用しないと通えない距離での居住は若い商店 主に、それぞれ比較的多く見られた注山。

また、所有形態別（表 15、表 16）に見ると、自店人の居住形態 は、住居併用および徒歩 5 分以内での居住の割合が高いのに対し て、借店人の居住形態は総じて車や電車等を利用しないと通えな い距離での居住の割合が高いことがわかるが、借店人の半数以上 が徒歩 15 分以内（約 $1 \mathrm{~km}$ 圈内）に居住していることからも分か るように、徒歩圈での居住ニーズは高いことが推察される注ら)。 地域別に見ると、両区共に、ほぼ同様の傾向が見られるが、金

表 11、業璉別の商店の使途（保土ヶ谷区 ・現在）

\begin{tabular}{|c|c|c|c|c|c|c|c|c|c|c|}
\hline & 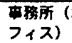 & 缽売高 & 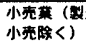 & 语小茾 & 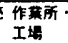 & 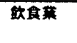 & 揊 & 萭-ピス & 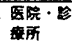 & その他 \\
\hline 土っ谷区 & $\begin{array}{c}14 \\
6.1 \%\end{array}$ & 4 & $\begin{array}{c}96 \\
46\end{array}$ & 14 & $\begin{array}{c}2 \\
0996\end{array}$ & 38 & ${ }_{0}^{2}$ & $\begin{array}{c}33 \\
143 \%\end{array}$ & 11 & 16 \\
\hline 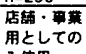 & 8 & 3 & 45 & 9 & 0 & 27 & 2 & 17 & 11 & 11 \\
\hline 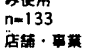 & $6.0 \%$ & $2.3 \%$ & $33.8 \%$ & $6.8 \%$ & $0.0 \%$ & $20.3 \%$ & $1.5 \%$ & $12.8 \%$ & $8.3 \%$ & $8.3 \%$ \\
\hline $\begin{array}{l}\text { 用と住居の } \\
\text { 西方に使用 }\end{array}$ & 3 & 0 & 33 & 2 & 1 & 7 & 0 & 13 & 0 & 0 \\
\hline$n=59$ & $5.1 \%$ & $0.0 \%$ & $55.9 \%$. & $3.4 \%$ & $1.7 \%$ & $11.9 \%$ & $0.0 \%$ & $22.0 \%$ & $0.0 \%$ & $0.0 \%$ \\
\hline
\end{tabular}

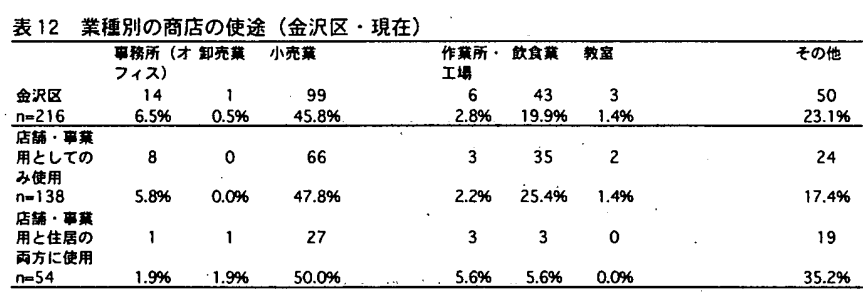

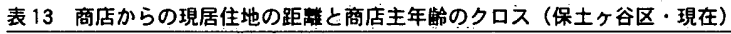

\begin{tabular}{|c|c|c|c|c|c|c|c|c|}
\hline 倡土っ谷区 & 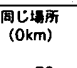 & $\begin{array}{l}\text { 徒督5 分以内 } \\
(300 \mathrm{~m})\end{array}$ & 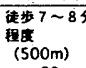 & 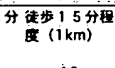 & 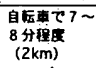 & 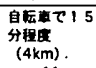 & 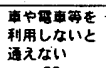 & の地 \\
\hline 全体 & 72 & 39 & 20 & 18 & 4 & 11 & 53 & 2 \\
\hline$n=219$ & $32.9 \%$ & $17.8 \%$ & 9.196 & $8.2 \%$ & $1.8 \%$ & $5.0 \%$ & $24.2 \%$ & $0.9 \%$ \\
\hline $20 \mathrm{ft}$ & 0 & 1 & 0 & 0 & 0 & 0 & 0 & 0 \\
\hline & $0.0 \%$ & $100.0 \%$ & $0.0 \%$ & $0.0 \%$ & $0.0 \%$ & $0.0 \%$ & $0.0 \%$ & $0.0 \%$ \\
\hline 30 tt & 2 & 2 & 1 & 1 & 0 & 2 & 3 & 0 \\
\hline$n=11$ & $18.2 \%$ & $18.2 \%$ & $9.1 \%$ & $9.1 \%$ & $0.0 \%$ & $18.2 \%$ & $27.3 \%$ & $0.0 \%$ \\
\hline $40 H$ & 5 & 5 & 6 & 0 & 2 & 2 & 6 & 1 \\
\hline$n=27$ & $18.5 \%$ & $18.5 \%$ & $22.2 \%$ & $0.0 \%$ & $7.4 \%$ & $7.4 \%$ & $22.2 \%$ & $3.7 \%$ \\
\hline 50 HE & 16 & 9 & 4 & 11 & 1 & 5 & 18 & 1 \\
\hline$n=65$ & $24.6 \%$ & $13.8 \%$ & $6.2 \%$ & $16.9 \%$ & $1.5 \%$ & $7.7 \%$ & $27.7 \%$ & $1.5 \%$ \\
\hline 60 H & 29 & 16 & 6 & 3 & 1 & 2 & 21 & 0 \\
\hline$n=78$ & $37.2 \%$ & $20.5 \%$ & $7.7 \%$ & $3.8 \%$ & $1.3 \%$ & $2.6 \%$ & $26.9 \%$ & $0.0 \%$ \\
\hline 70 tt & 15 & 6 & 3 & 3 & 0 & 0 & 3 & 0 \\
\hline$n=30$ & $50.0 \%$ & $20.0 \%$ & $10.0 \%$ & $10.0 \%$ & $0.0 \%$ & $0.0 \%$ & $10.0 \%$ & $0.0 \%$ \\
\hline 80代的上 & 5 & 0 & 0 & 0 & 0 & 0 & 2 & 0 \\
\hline & 71.44\% & $0.0 \% \%$ & & $0.0 \%$ & & & $28.6 \%$ & $0.0 \%$ \\
\hline
\end{tabular}

表 14 商店からの現居住地の距離と商店主年柃のクロス（金沢区・現在）

\begin{tabular}{|c|c|c|c|c|c|c|c|c|}
\hline 金沢区 & $\begin{array}{c}\text { 同C然 } \\
(0 \mathrm{~km})\end{array}$ & 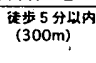 & 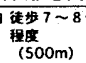 & 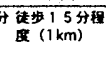 & 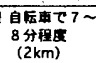 & 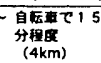 & 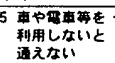 & その地 \\
\hline $\begin{array}{l}\text { 金件 } \\
n=204\end{array}$ & 62 & 40 & & 18 & & & & 1 \\
\hline$n=204$ & $30.4 \%$ & $19.6 \%$ & $8.8 \%$ & $8.8 \%$ & $4.9 \%$ & $4.9 \%$ & $22.1 \%$ & $0.5 \%$ \\
\hline $20 \mathrm{Ht}$ & 0 & 0 & 0 & 1 & 0 & 0 & 0 & 0 \\
\hline & $0.0 \%$ & $0.0 \%$ & $0.0 \%$ & $100.0 \%$ & $0.0 \%$ & $0.0 \%$ & $0.0 \%$ & $0.0 \%$ \\
\hline $30 \mathrm{tt}$ & 1 & 2 & 0 & 1 & 2 & 1 & 4 & 1 \\
\hline & $8.3 \%$ & $16.7 \%$ & $0.0 \%$ & $8.3 \%$ & $16.7 \%$ & $8.3 \%$ & $33.3 \%$ & $8.3 \%$ \\
\hline $40 \mathrm{Ot}$ & 6 & 5 & 2 & 2 & 2 & 2 & 12 & 0 \\
\hline$n=31$ & $19.4 \%$ & $16.1 \%$ & $6.5 \%$ & $6.5 \%$ & $6.5 \%$ & $6.5 \%$ & $38.7 \%$ & $0.0 \%$ \\
\hline 50 te & 13 & 19 & 11 & $\begin{array}{c}0.30 \\
7\end{array}$ & 3 & 4 & 21 & $0^{\circ}$ \\
\hline$n=78$ & $16.7 \%$ & $24.4 \%$ & $14.1 \%$ & $9.0 \%$ & $3.8 \%$ & $5.1 \%$ & $26.9 \%$ & $0.0 \%$ \\
\hline 60 te & 22 & 7 & 4 & 6 & 2 & 1 & 5 & 0 \\
\hline$n \times 47$ & $46.8 \%$ & $14.9 \%$ & $8.5 \%$ & $12.8 \%$ & $4.3 \%$ & $2.1 \%$ & $10.6 \%$ & $0.0 \%$ \\
\hline $70 \mathrm{At}$ & 14 & 6 & 0 & 0 & 1 & 1 & 3 & 0 \\
\hline & $56.0 \%$ & $24.0 \%$ & $0.0 \%$ & $0.0 \%$ & $4.0 \%$ & $4.0 \%$ & $12.0 \%$ & $0.0 \%$ \\
\hline 80 代以上 & 6 & 1 & 1 & 1 & 0 & 1 & 0 & 0 \\
\hline$n=10$ & $60.0 \%$ & $100 \%$ & $10.0 \%$ & $.10 .0 \%$ & $0.0 \%$ & $10.0 \%$ & $0.0 \%$ & 0.096 \\
\hline
\end{tabular}

表 15 商店からの現居住地の距䠰と商店の所有形態のクロス（保土ヶ谷区・現在）

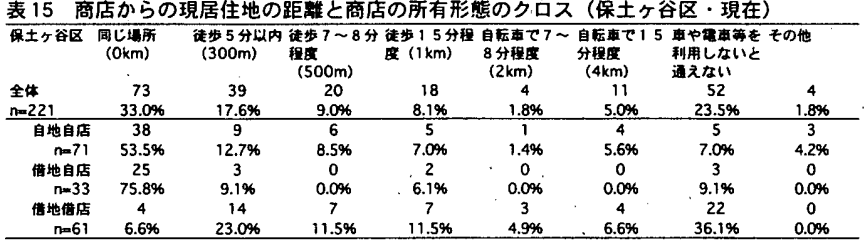

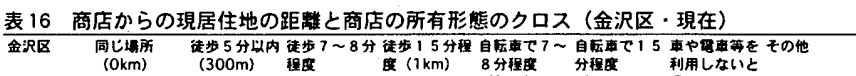

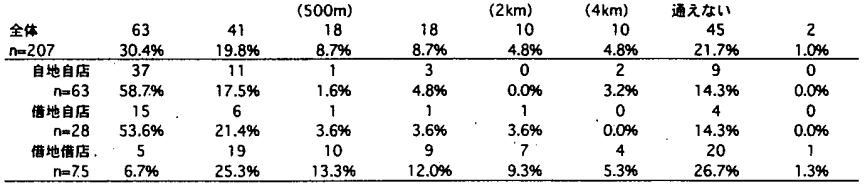

表 17. 商店の所有形態と商店主年疑の

\begin{tabular}{|c|c|c|c|}
\hline $\begin{array}{l}\text { 㔀土ケ谷区 } \\
\text { 全俈 } \\
n=164\end{array}$ & $\begin{array}{c}\text { 自地自店 } \\
71 \\
43.3 \% \\
\end{array}$ & $\begin{array}{c}\text { 壦地自店 } \\
33 \\
20.1 \% \\
\end{array}$ & $\begin{array}{c}\text { 借地措店 } \\
60 \\
36.6 \% \\
\end{array}$ \\
\hline $20 \mathrm{Ht}$ & 0 & 0 & 0 \\
\hline $301 t^{n=0}$ & 4 & 1 & 4 \\
\hline & $44.4 \%$ & $11.1 \%$ & $44.4 \%$ \\
\hline $40 \mathrm{Ht}$ & 10 & 2. & 11 \\
\hline$n=23$ & $43.5 \%$ & $8.7 \%$ & $47.8 \%$ \\
\hline $501 t$ & 20 & 7 & 18 \\
\hline$n=45$ & $44.4 \%$ & $15.6 \%$ & $40.0 \%$ \\
\hline 60 tt & 20 & 15 & 19 \\
\hline$n=54$ & $37.0 \%$ & $27.8 \%$ & $35.2 \%$ \\
\hline 701t & 12 & & \\
\hline & $46.2 \%$ & $26.9 \%$ & $26.9 \%$ \\
\hline 80 代以上 & 5 & 1 & 1 \\
\hline$n=7$ & $71.4 \%$ & $14.3 \%$ & $14.3 \%$ \\
\hline
\end{tabular}

表 18 商店の所有形態と商店主年桧の

\begin{tabular}{|c|c|c|c|}
\hline 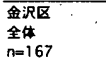 & $\begin{array}{c}\text { 自地自店 } \\
63 \\
37.7 \%\end{array}$ & $\begin{array}{c}\text { 港地自店 } \\
16.8 \%\end{array}$ & $\begin{array}{c}\text { 笛地散店 } \\
45.55\end{array}$ \\
\hline $201 t$ & 1 & 0 & 0 \\
\hline$n=1$ & $100.0 \%$ & $0.0 \%$ & $0.0 \%$ \\
\hline $30+t$ & 1 & 1 & 9 \\
\hline$n=11$ & $9.1 \%$ & $9.1 \%$ & $81.8 \%$ \\
\hline $40+t$ & 8 & 0 & 18 \\
\hline$n=26$ & $30.8 \%$ & $0.0 \%$ & $69.2 \%$ \\
\hline 50te & 16 & & 36 \\
\hline-58 & $27.6 \%$ & $10.3 \%$ & $62.1 \%$ \\
\hline 60 代 & 20 & 10 & 9 \\
\hline$n=39$ & $51.3 \%$ & $25.6 \%$ & 23.1\% \\
\hline 701t & 13 & 6 & 3 \\
\hline$n=22$ & $59.1 \%$ & $27.3 \%$ & $13.6 \%$ \\
\hline $\begin{array}{c}80 \text { 代上上 } \\
n=10\end{array}$ & $\begin{array}{c}4 \\
40.0 \%\end{array}$ & $\begin{array}{c}5 \\
50.0 \%\end{array}$ & $\begin{array}{c}1 \\
10.0 \%\end{array}$ \\
\hline
\end{tabular}


沢区では、自店人であっても、車や電車等を利用しないと通えな い距離に居住する割合が比較的高く、借店人との差が保土ケ谷区 ほど顕著に見られないのが特徵的であった。

金沢区では、大規模な宅地開発が段階的に進んでおり、郊外部 において特徵的に見られるこうした大規模宅地開発が、商人家族 の居住地の二極化をうながしたものと考えられる。

\section{4 住み替え経験者の居住動向}

開業以降、住み替え経験のある場合についてその変遷を回答し てもらったところ、住み替え経験がある商人家族は全体の約 4 割 であり、両区共に住み替え回数は「1回」が最も多かったが、保 土ヶ谷区における調査では 2 回以上の住み替え経験を有する者が 過半数を占めた（表 19、表 20）。

これは、比較的古い商店が保土ヶ谷区に多く存在することにも 起因すると考えられるが、むしろ、保土ヶ谷区は比較的古くから 市街化が進行しており、商店街周辺地域に多様な居住地を有して いるためと考えられる。

開業時期別に住み替え経験の有無をみると、高度成長期に開業 した商人が両区共に最も高い住み替え経験率を示しておりま16)、営 業年数が長いほど住み替え経験率が高くなるわけではないことが 分かる。

また、自店人がもともと「住み替える予定はなかった」り、「住 み替えるかどうか未定だった」りする割合が比較的高いのに対し、 借店人は当初から「住み替える予定だった」割合が高い（図6 生 ${ }^{17)}$ )。表 21 、表 $22^{\text {注 18) }}$ より、借店人は住まいもまた借地借家であ る場合が多く、潜在的に流動性の高い存在であることが同える。

図7、図8は住み替え経験者のうち、最近 1 回分の住み替えの 経緯について、同町内・異町内間の移動之商店への入居（住居併 用）の有無のそれぞれについて計 4 つの場合に分けて地図上に図 示したものである注 19)。

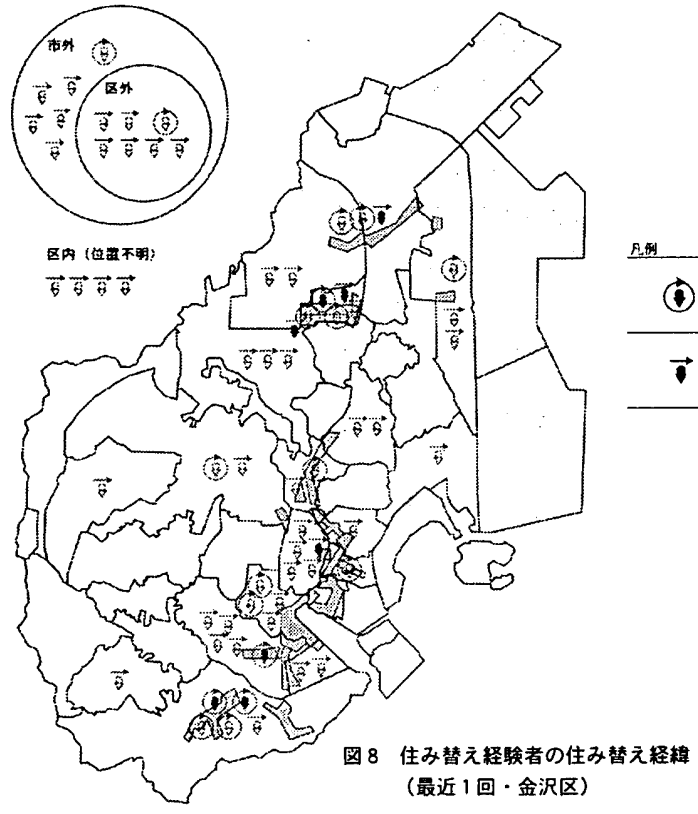

(最近 1 回・金沢区)
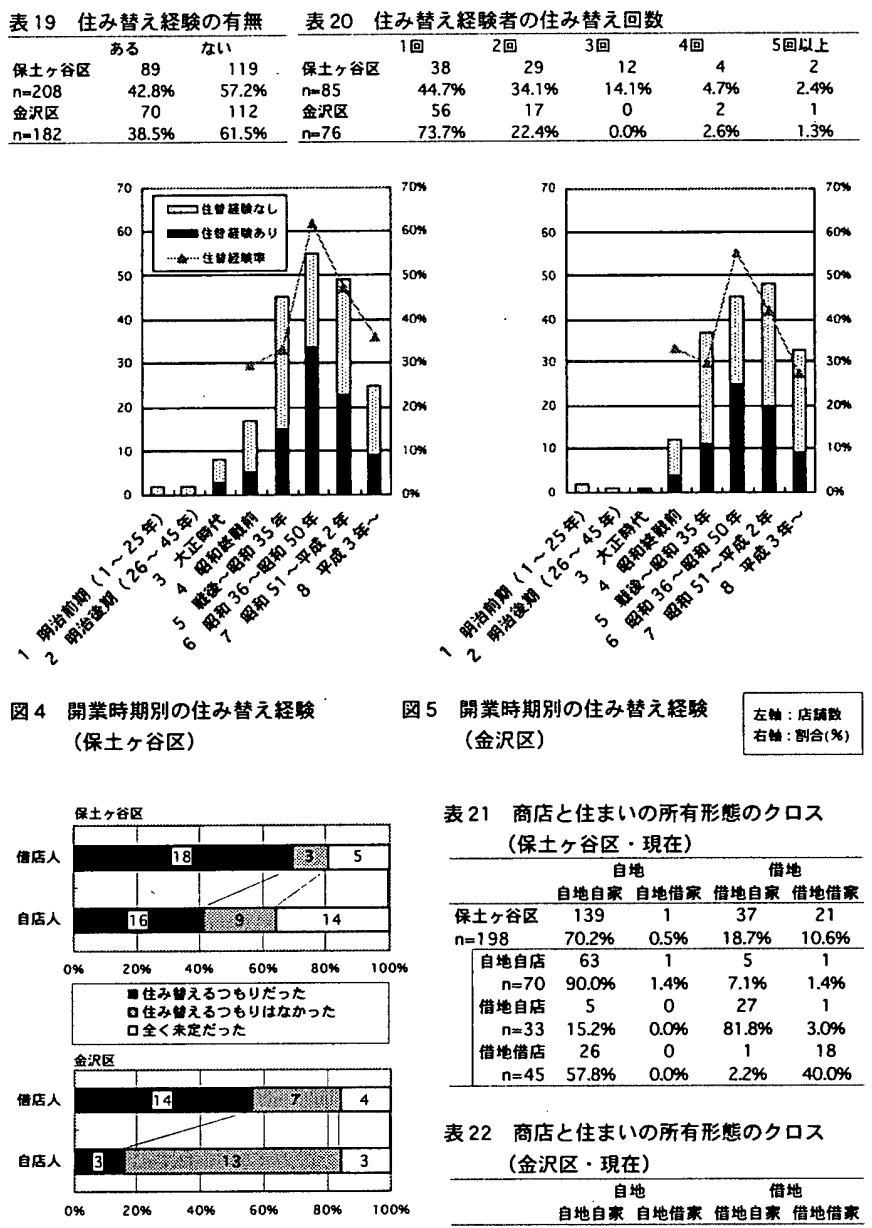

表 21 商店と住まいの所有形態のクロス (保土ヶ谷区・現在)

\begin{tabular}{|c|c|c|c|c|}
\hline \multirow{3}{*}{$\begin{array}{l}\text { 保土ち谷区 } \\
n=198\end{array}$} & \multicolumn{2}{|c|}{$\begin{array}{c}\text { 自地 } \\
\text { 的自家地借的 }\end{array}$} & \multicolumn{2}{|c|}{ 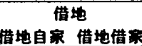 } \\
\hline & 139 & 1 & 37 & 21 \\
\hline & $70.2 \%$ & $0.5 \%$ & $18.7 \%$ & $10.6 \%$ \\
\hline 自地自店 & 63 & 1 & 5 & 1 \\
\hline$n=70$ & $90.0 \%$ & $1.4 \%$ & $7.1 \%$ & $1.4 \%$ \\
\hline 借地自店 & 5 & 0 & 27 & 1 \\
\hline$n=33$ & $15.2 \%$ & $0.0 \%$ & $81.8 \%$ & $3.0 \%$ \\
\hline 剒地借店 & 26 & 0 & 1 & 18 \\
\hline$n=45$ & $57.8 \%$ & $0.0 \%$ & $2.2 \%$ & $40.0 \%$ \\
\hline
\end{tabular}

表 22 商店と住まいの所有形㮩のクロス (金沢区・現在)

\begin{tabular}{|c|c|c|c|c|}
\hline & \multirow{2}{*}{\multicolumn{2}{|c|}{ 自地自自自自地借㴚 }} & \multirow{2}{*}{\multicolumn{2}{|c|}{ 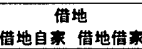 }} \\
\hline & & & & \\
\hline & 131 & 0 & 26 & 24 \\
\hline & $72.4 \%$ & $0.0 \%$ & $14.4 \%$ & $13.3 \%$ \\
\hline 自地自店 & 58 & 0 & 1 & 1 \\
\hline$n=60$ & $96.7 \%$ & $0.0 \%$ & $1.7 \%$ & $1.7 \%$ \\
\hline 僣地自店 & 7 & 0 & 20 & 1 \\
\hline$n=28$ & $25.0 \%$ & $0.0 \%$ & $71.4 \%$ & $3.6 \%$ \\
\hline 借地借店 & 40 & 0 & 4 & 19 \\
\hline$n=63$ & $63.5 \%$ & $0.0 \%$ & $6.3 \%$ & $30.2 \%$ \\
\hline
\end{tabular}

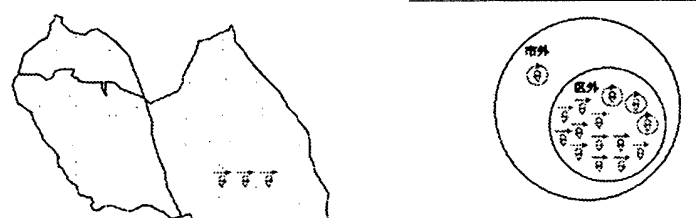
(商店の所有形態別) 
これによると、住み替えを繰り返しながらも、商店の周辺（同 町内か、もしくは、隣接町内）へ居住する傾向があることが両区 共に指摘できる。

また、商店への（再）入居（住居併用）が保土ヶ谷区で 63 例中 13 例、金沢区で 49 例中 8 例見られるが、これらは商店を自己所 有している場合にほぼ限られ、逆に借店人は自店人に比べ区外や 市外への転出傾向がやや強いことが分かる（表 23、図 9 注20)。

借店人の多くが住まいもまた借家であることから、地域内居住 の継続に対するインセンティブが㗢きにくく、結果的に地域外へ の転出傾向を強めているものと思われる。

\section{5 居住地の選択基準}

最後に、仮に将来住み替えを行うとした場合に、表 24 に示した $8 つ$ 項目のそれぞれについて、どの程度重視するのか、5段階 評価を行ってもらい、居住地の選択基準について因子分析を行っ た。その結果、「住みやすさ」（因子No.1）「営業のしやすさ」(因 子No.2）の 2 因子が抽出され、この 2 つが商人家族が居住地を選 択する際の重要な選択基準であることが分かった（表 25、図 10）。

なお、自店人、借店人のそれぞれの属性別平均をとつたが、ほ とんど差は見られなかったことから、この 2 因子は商店の所有形 態に関わらず商人固有のものであると考えられる。

また、この 2 因子を用いて、各サンプルの因子得点をプロット したものが図 11 であり、両因子の関俰から、「営業重視派」「生活 重視派」「両立派」「無関心派」の4つのグループに分けてみた。

表 26 は、これをさらに、保土ヶ谷区、金沢区において、それぞ れのグループ毎に集計したものである。

両区に共通して、無関心派が最も多いが、無関心派を除くと、 保土ヶ谷区は両立派が最も低い割合を示すのに対し、金沢区では 両立派が最も高い割合を示すのが特徵的であった。

保土ヶ谷区は比較的古くから市街化が進行しており、居住地と しては多様であるが、そもそも両立する立地条件の土地が少ない こと、また、金沢区では、宅地開発地域における新規商店の若手 商人が相当数存在しており、彼らの志向が反映されたことなどが 要因として考えられる。

\section{4 聞き取り調査結果と考察}

これまでのアンケート調查結果を補足的に理解するために、商 人への聞き取り調査を 2000 年 12 月から 2001 年 7 月にかけて別 途実施した。対象商店街は金沢区金沢八景駅前の商店街であり、 130 余店舗の近隣型商店街である。

協力の得られた 10 商店に対し、営業の移り変わり（店舗史）と 住まいや暮らし方の変化（住居史）をそれぞれ時系列で尋ねた。

表 $27 〜 29$ はこのうち、比較的古くから営業を続けている小売 店 3 店を抜粋したものであり、取扱商品はそれぞれ、食料品一般、 自転車、野菜・果物、である。

このうち、食料品店と八百屋は、住居併用の居住形態から専用 店舗化した例であり、自転車店は子世帯のみが住み替えた例（車 で 10 分程度の所に住み替え）である。また、食料品店と八百屋に ついては住み替え先はいずれも徒歩圈である。

表からは、「住一商」関係が変化する動機として、事業の変更、

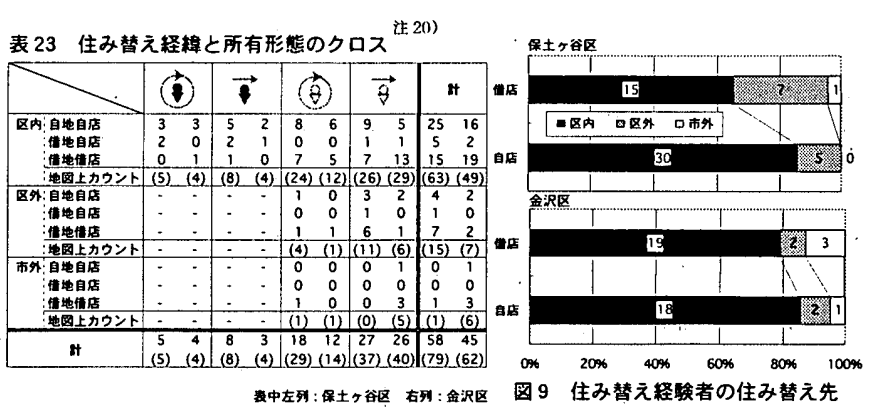

\begin{tabular}{|c|c|c|c|c|c|c|c|c|}
\hline 全体 & 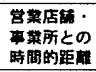 & 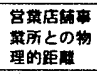 & $\begin{array}{l}\text { 交通の利便 } \\
\text { 性 }\end{array}$ & 生活懪塂 & 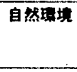 & 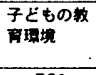 & 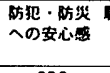 & 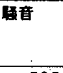 \\
\hline 拿財。 & 565 & 612 & 567 & 586 & 671 & 761 & 633 & 595 \\
\hline 平昀 & 1.63 & 1.76 & 1.63 & 1.69 & 193 & 219 & 182 & 1.71 \\
\hline 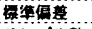 & 0.94 & 0.98 & 0.89 & 0.82 & 0.93 & 107 & 0.91 & 0.90 \\
\hline サンフル & 347 & & & & & & & \\
\hline
\end{tabular}

表 25 固有値表 (回転後・バリマックス法)

\begin{tabular}{|c|c|c|c|}
\hline 因子融 & 二乗和 & 惫与率 & 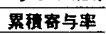 \\
\hline 因子Na 1 & 2.544055 & $31.80 \%$ & 31.8 \\
\hline 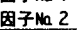 & 2.119216 & $26.49 \%$ & 58.2 \\
\hline
\end{tabular}

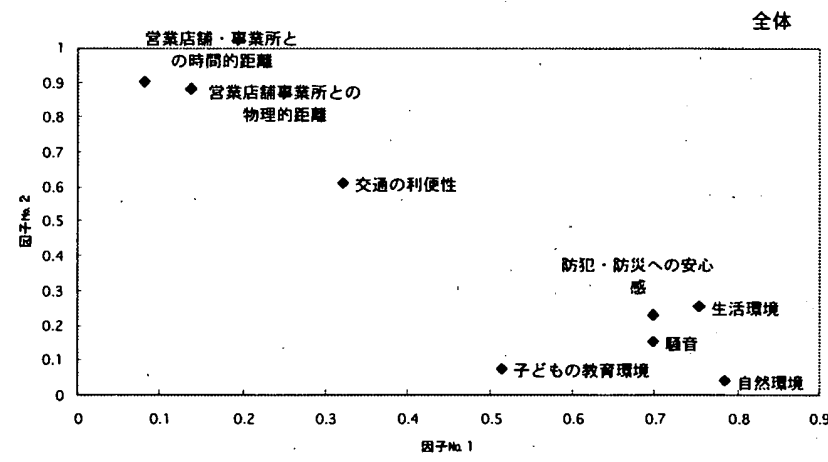

图 10 因子負荷量のプロット（回枟後・バリマックス法）

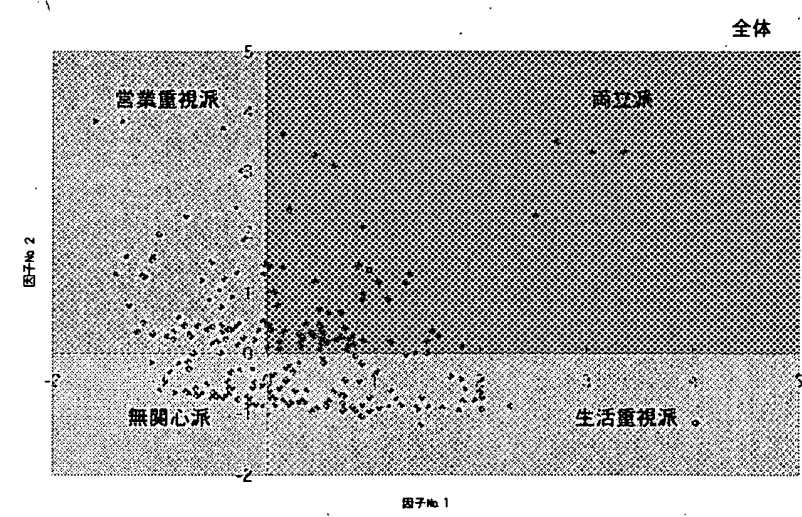

図11 因子得点のブロット（回転後・バリマックス法）

\begin{tabular}{lcccc} 
表 26 & 象限別の因子得点数 & & & \\
& 両立派 & 生活重視派 & 無関心派 & 営業重視派 \\
\hline 保土ケ谷区 & 34 & 46 & 57 & 38 \\
$\mathrm{n}=175$ & $19.8 \%$ & $26.7 \%$ & $33.1 \%$ & $22.1 \%$ \\
金沢区 & 46 & 37 & 56 & 33 \\
$\mathrm{n}=172$ & $26.3 \%$ & $21.1 \%$ & $32.0 \%$ & $18.9 \%$ \\
\hline
\end{tabular}


店舖の拡大、家族数の増加、子どもの成長などさまざまな要因が 複合していると読みとれるが、住み替えを誘発する直接的なきつ かけとなっているのはいずれも居住継続上の要因であった。

\section{5 まとめ}

\section{1 両区に共通して見られた特徵}

(1)商店の使途について

・商店の店舗専用としての使用は借店人に多く見られ、逆に、住 居併用は自店人に多く見られる

・商店を自己所有しない商人（借店人）が増加傾向にあり、逆に、 自店人は減少傾向にある

(2)現居住地の特徵について

- 過半数の商人家族が、徒歩 5 分以内の近隣に居住している

・借店人であっても、徒歩圈での居住ニーズは高いが、一方で、 車や電車等を利用しないと通えない距離に居住する割合も高い

(3)住み替え経験者の居住動向について

・高度成長期以降に開業した商人に住み替え志向が強い

・借店人はもともと「住み替える予定」だった割合が高い

(4)居住地の選択基準について

・「住みやすさ」と「営業のしやすさ」の 2 つ要因が、商人家族 固有の居住地選択の基準である

・営業と生活のどちらを結果的に重視するかについては、個々の 商店の経年的変化によるところが大きい

\section{2 両区で相違が見られた特徵}

(1)商店の使途について

- 保土ヶ谷区は金沢区に比べて小売商店の住居併用の割合が比較 的高い

(2)現居住地の特徵について

・金沢区は保土ヶ谷区に比べて、自店人であっても車や電車等を 利用しないと通えない距離に居住する割合が比較的高い

(3)住み替え経験者の居住動向について

・保土ヶ谷区は金沢区に比べて、複数回の住み替え経験を有する 商人家族が比較的多い

(4)居住地の選択基準について

- 金沢区は保土ヶ谷区に比べ、居住地の選択基準として「住みゃ すさ」「営業のしやすさ」の両方を重視する商人家族が比較的多い

\section{6 考察}

保土ヶ谷区は金沢区に比べて商人の高齢化が進んでいる傾向が やや強かったことからも分かるように、比較的早い段階から市街 化が進行しており、古くから居住地と一体的に営業している小売 商店の割合が大きく、そうした商店は住居併用の居住形態を保っ ている。

一方で、金沢区は古くからの商店に加え、周囲で進行する大規 模宅地開発に伴う新規商店や、遠方からの通いの商人が増加し、 商人家族の居住地の二極化の進行が指摘できる。

一般的に宅地開発での商店誘致に際しては、住居併用の居住形 態に配慮されることは少なく、店舗専用として借店する場合がほ とんどであり、こうしたことも通いの商人が増加する要因の 1 つ

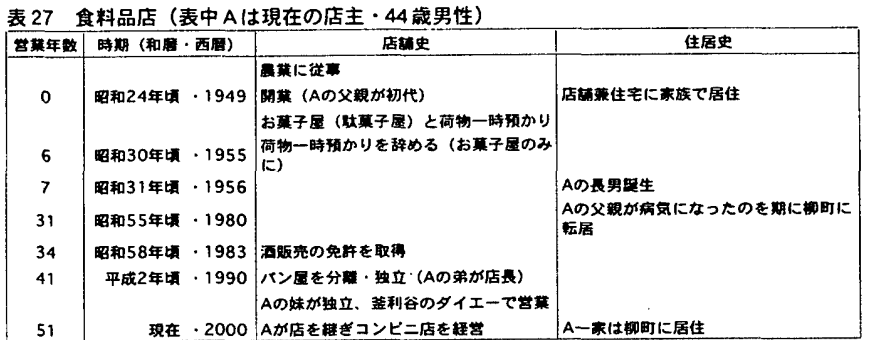

\begin{tabular}{|c|c|c|c|c|}
\hline 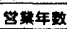 & 時期 (和骨. & - 西畨) & 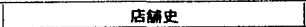 & 住居史 \\
\hline 0 & 略和2年 & .1927 & 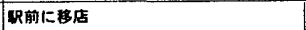 & \\
\hline 4 & 略和6年比 & .1931 & & 物を改道して住し（兄第合めて10人 \\
\hline & 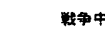 & & Aの夫の父親が后に出ていた & \\
\hline 26 & 明和28年 & .1953 & & Aの興男罢生 \\
\hline 28 & 略和30年 & $\cdot 1955$ & 面用として自䣲車かよく责れた & \\
\hline & 昭和35年江 & $\cdot 1960$ & & 3家族20人くらいて閣居 \\
\hline 33 & 昭和35年 & $\cdot 1960$ & 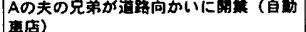 & 手にない、Aの夫の只弟家辰かた居 \\
\hline 53 & 昭和55年比 & .1980 & & 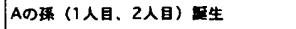 \\
\hline 62 & 平成元年 & $\cdot 1989$ & & 手泱になり、Aの畏男家族が祬居 \\
\hline 63 & 平成2年憤 & $\cdot 1990$ & & Aの係 (3人目) 影生 \\
\hline 73 & 现在 & $\cdot 2000$ & 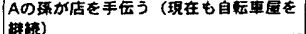 & 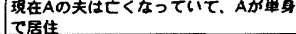 \\
\hline
\end{tabular}

\begin{tabular}{|c|c|c|c|c|}
\hline 点年年 & 时約（和周 & 西用) & 后铺史 & 住居史 \\
\hline 0 & 昭和 12年 & $\cdot 1937$ & 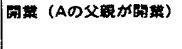 & 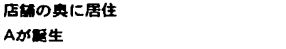 \\
\hline 23 & 略和35年 & $\cdot 1960$ & 居を引き維く & 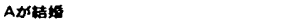 \\
\hline 32 & 昭和 44年 & $\cdot 1969$ & & Aの長女蜝 \\
\hline 34 & 略和46年 & $\cdot 1971$ & & Aの次女圆生 \\
\hline 50 & 昭和 62 年 & $\cdot 1987$ & 店を挞珹 & 手狭になり，近くのマンションへ枟居 \\
\hline 63 & 现在 & $\cdot 2000$ & 再用店到 & 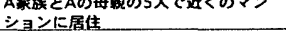 \\
\hline
\end{tabular}

となっていると考えられる。

言うまでもなく、商人家族が自身の営業店舗と住まいを一にす る、いわゆる店舗併用住宅が、昭和初期から戦後にかけて一般的 に見られた商店の姿であり、こうした商店が連続する街並みが近 隣型商店街の原風景でもあったが、戦後復興期から高度成長期に かけての商店の急激な增加と、それに伴う土地細分化の進行によ り、結果的に狭小な居住環境を強いられた商人家族は、ライフス タイルの多様化とも相まって、狭小な商店における居住継続を断 念せざるをえなくなったと考えられる。

それでも商店を自己所有している場合には、地域内に明確な足 がかりを得ることから、住み替えを繰り返しながらも徒歩圈での 居住を継続する傾向にあった。

近年指摘される商人家族の地域外居住の問題は、むしろ、高度 成長期以降に開業した商店が、そもそも借店である場合が多いこ とに起因し、地域に明確な足がかりを持たないまま営業を継続す ることで表出した結果であるとも指摘できる。

これらのことから、店舗の所有性を高めることが商人家族の地 域内居住を支えることにつながると指摘でき、このためにはまず、 (1)「店舗所有の継続できる仕組みづくりを進めていくこと」が必 要と考えられる。

また、現在の細分化された土地所有状況の中では、(2)「新規商 店の取得支援や、閉業した既存商店の所有権の移転促進など、店 埔所有の流動性を高めていくこと」も必要であると考えられる。

さらに、借店人であっても、徒歩圈での居住ニーズが高かった ことからも分かるように、(3)「良質でアフォーダブルな住宅を近 隣で供給していくこと」も有効であると考えられる。

本研究では所有関係に焦点をあてたが、商店従事者や所有者の 年齢、家族形態による居住動向への影響に関して、さらに調查・ 分析・考察することも必要であると考えられる。 


\section{謝辞}

本研究の一部は、（財）日本科学協会平成 13 年度笹川科学研究 助成を得て行われた。ここに記して謝意を表する。

\section{【脚注】}

1）参考文献 1）～4）参照

2）本研究では、家族営業による店舗・事業所か、そうでなくても小規模（従 業員が数人程度）の店舖・事業所を「商店小商店の営業者を「商人」とする。 3）参考文献 5）～7）参照

4）参考文献 4）において、商店街の現状と課題について報告がなされており、 そのなかに、徒歩圈に居住する商人の割合についてまとめられているが、その 動機や住み替え経緯等の詳紐については触れられていない。

5）全国商店街振興組合連合会の推計による。ただし、組織化されていない商 店街も多数存在するため、正確な数の把握はできない。組織として明確なもの で全商連が把握しているものは、全国で 13,259 商店街 (平成 15 年 6 月見在)。 6）参考文献 4）によると、商店街は大きくその商圈により、「近隣型」「地域 型」「広域型」「超広域型」の 4 つの区分に分けられ、このうち近隣型商店街は 「最奇品中心で、地元主婦が日用品等を徒歩又は自転車などにより、日常性の 買い物をする商店街」とされる。また、それぞれの比率は近隣型 $54.3 \%$ 、地域 型 $28.2 \%$ 、広域型 $8.1 \%$ 、超広域型 $2.0 \%$ でる。なお、本研究では、取り扱 い商品による商店街の区分が困難であるため、都市計画上おおむ执 $1 / 2$ 以上 が近隣商業地域に含まれる商店街を近隣型商店街と定義することとする。

7）自地借店は該当なし

8）両区計で $1 \%$ 有意

9）自店率 $=\lceil$ 自店人（自地自店人 + 借地自店人）／総数」、借店率 $=\lceil$ 借店人 (借地借店人). /総数」とする

10）高度成長期以降に開業した借店のなかには、地域外資本によるチェーン店 も相当数含まれているものと考えられる。

11）参考文献 8）参照

12）両区計で $5 \%$ 有意。なお、保土々谷区調查では項目を追加している。

13）表 13、14 および表 $15 、 16$ および表 $17 、 18$ のそれぞれについて、雨区計 で $1 \%$ 有意。なお、徒歩 $=$ 約 $4 \mathrm{~km} / \mathrm{h}$ 、自転車 $=$ 約 $16 \mathrm{~km} / \mathrm{h}$ として算出 14）当初は睵住近接は一般的であったと考えられ、商店からの距離について。 商店主の年秢の要因も大きく效いているものと考えられるが、本研究では所有 関倸による差買の分析に主眼を置いた調查を実施しており、年路による影響に ついては今後の調查・分析課題である。
15）表 17 、表 18 より、自店人は比較的高踰の商店主が多く、借店人は比輅的 若い商店主が多いことが分かるが、年㱓による影響については、注 14）の通 り、今後の調查・分析課題である。

16）住み替え経験率＝「住み替えた人の数／総数」とする。なお、大正時代以 前に開業した商店数が少ないため、ここでは昭和時代以降に開業した商店につ いて図示している。

17）两区計で $1 \%$ 有意

18）両区計で $1 \%$ 有意

19）各区内の区分線は町境界線。なお、保土ヶ谷区和田町商店街については、 調查協力が得られず。

20）サンプル数が少なかったため有意差は見られなかったが、商店の所有形態 別の現居住地の関保（表 17、表 18）では有意差が見られていることから、解 釈上問題はないものと考えられる。

21）表中の数值と、地図上のカウント数が異なるのは、アンケートにおいて、 住み替え経緯のみを回答している場合があるため。

\section{【参考文献】}

1）田中宏育、中井検裕 : 東京都心の近降型商店街の動向に関する研究、日本 都市計画学会学術研究論文集、通巻 31 号、pp.517-522、1996 2）阿部隆史他 4 名：東京都における近隣型商店街の支援事業に関する研究一 その 1 商店街組合へのヒアリンク調查による事業実施後の現況一、日本建筑 学会大会学術講演梗概集 F-1 分冊、pp.713-714、1999

3）鬼山功他 4 名：東京都における近隣型商店街の支援事業に関する研究一そ の 2 商店街来街者に対するヒアリング調查による評価一、日本建策学会大会 学術講演梗概集 F-1 分冊、pp.715-716、1999

4）流通政策研究所、商店街実態調查報告書、2000.11

5）建築思潮研究所、[建策設計資料]19店舗併用住宅一鄗住建築、建筑資糊研究 社、 1987.12

6）建策思潮研究所、[建策設計資料]84 店舗併用住宅一商住建策 2 、建策資料研 究社、2001.12

7）吉野国夫、タウンリソートとしての商店街、学芸出版社、1994.7

8）木野村友宏、藤剛泰宽、小滰一正、大原一興：土地建物の所有関係からみ た店舗・事業所経営者の居住地選択の動问－住商併存の住まい方に関する研究 その 3 -、日本建築学会大会学術講演梗概集 F-1 分冊、pp.1189-1190、2002

(2004年 5 月 10 日原稿受理，2004年 9 月 10 日採用決定） 